\title{
Hubungan Tingkat Pendidikan dengan Kepatuhan Berobat Penderita TB Paru di Wilayah Kabupaten Lamongan pada Januari 2016 - Desember 2018
}

\author{
Relationship of Education Level with Medical Compliance of Pulmonary TB PATIENTS in The \\ Region of Lamongan District in January 2016 - December 2018 \\ Sholihul Absor ${ }^{*}$, Annisa Nurida ${ }^{2}$, Yelvi Levani $^{3}$, Wichda Shirosa Nerly ${ }^{4}$ \\ ${ }_{1,2,3}$ Dosen Fakultas Kedokteran Universitas Muhammadiyah Surabaya \\ ${ }^{4}$ Program Sarjana Fakultas Kedokteran Universitas Muhammadiyah Surabaya \\ *Penulis korespondensi: Sholihul Absor. Email: shirosanerly@gmail.com
}

\begin{abstract}
ABSTRAK
Latar Belakang: Indonesia menduduki peringkat ke-3 jumlah penderita Tuberkulosis (TB) terbanyak di dunia, serta angka kematian TB setiap tahunnya sekitar 20\% dari jumlah penderita TB baru. Pengobatan pada TB paru rentan untuk terjadi putus berobat (drop out) yang bisa disebabkan oleh beberapa faktor, salah satunya adalah kepatuhan dalam berobat. Ketidakpatuhan terhadap pengobatan dapat disebabkan oleh berbagai faktor meliputi faktor predisposisi (Usia, jenis kelamin, tingkat pendidikan, dan pekerjaan), faktor pendorong (efek dari OAT), dan faktor penguat (dukungan keluarga, petugas kesehatan dan pelayanan kesehatan).

Tujuan: Studi ini dilakukan untuk mengetahui adanya hubungan antara tingkat pendidikan dengan kepatuhan berobat penderita TB paru di Wilayah Kabupaten Lamongan.

Metode: Studi ini menggunakan desain cross sectional dengan teknik pengambilan sampel yaitu simple random sampling pada 55 pasien TB paru drop out serta 55 pasien TB paru sembuh dari tahun 2016-2018 di Wilayah Kabupaten Lamongan. Pengambilan data menggunakan rekam medis dari Dinas Kesehatan.

Hasil: Hasil uji statistik menggunakan Koefisien Kontingensi terhadap hubungan tingkat pendidikan dan kepatuhan berobat pada pasien TB menunjukkan nilai yang signifikan p: 0,026 (p<0,05)

Kesimpulan: Hasil penelitian ini menunjukkan adanya hubungan antara tingkat pendidikan dengan kepatuhan berobat penderita TB paru.
\end{abstract}

Kata Kunci : Tuberkulosis paru, Tingkat pendidikan, Kepatuhan berobat

\section{ABSTRACT}

Background: Indonesia ranks $3 r d$ in the number of tuberculosis $(T B)$ cases in the world, and the annual TB mortality rate is around $20 \%$ of the number of new TB cases. Treatment of pulmonary TB is prone to drop out, which can be caused by several factors, one of which is adherence to treatment. Non-adherence to treatment can be caused by various factors, including predisposing factors (age, gender, education level, and occupation), driving factors (effects of OAT), and reinforcing factors (family support, health workers and health services). This study was conducted to determine the relationship between education level and compliance with pulmonary tuberculosis treatment in Lamongan Regency.

Methods: This study used a cross sectional design with a simple random sampling technique of 55 pulmonary TB patients dropping out and 55 pulmonary TB patients recovering from 2016-2018 in Lamongan Regency. Retrieving data using medical records from the Health Office.

Results: The results of statistical tests using the Contingency Coefficient on the relationship between education level and treatment compliance in TB patients showed a significant value of $p: 0.026(p<0.05)$.

Conclusion: The results of this study indicate a relationship between the level of education and adherence to treatment of pulmonary TB patients.

Keywords: Pulmonary tuberculosis, level of education, adherence to treatment 


\section{PENDAHULUAN}

Tuberkulosis (TB) merupakan penyakit menular yang utamanya menyerang paru-paru yang disebabkan oleh bakteri Mycobacterium tuberculosis. TB dapat ditularkan melalui udara atau droplet saat batuk yang terhirup oleh orang lain. ${ }^{1}$ Pasien TB aktif dapat menularkan 5-15 orang lain selama 1 tahun melalui kontak erat dan droplet. Berdasarkan data dari World Health Organization (WHO), pada tahun 2018 terdapat 10 juta kasus TB di seluruh dunia dengan angka kematian 1,5 juta kasus. Indonesia merupakan negara peringkat ke 3 dengan kasus TB terbanyak di seluruh dunia setelah Cina dan India. ${ }^{1}$ Terdapat kenaikan angka kematian TB di Indonesia setiap tahunnya sekitar $20 \%$ dari jumlah penderita TB baru. ${ }^{2}$

Di Indonesia sendiri, khususnya pada wilayah Jawa Timur Dinas kesehatan Lamongan (2017) mengatakan bahwa pada tahun 2015 sudah mengalami kenaikan angka keberhasilan (succes rate) $>91 \%$ dengan target $90 \%$ untuk pengobatan tuntas TB yang bila tidak diobati lebih dari $50 \%$ orang yang terinfeksi bisa meninggal. ${ }^{3}$ Namun, berdasarkan Badan Pusat Statistik (BPS) Kabupaten Lamongan (2018) pada tahun 2017 didapatkan ada 5 kecamatan yang masih mengalami kenaikan jumlah penderita TB paru dibandingkan dengan Kecamatan lainnya. Meliputi, Kecamatan Lamongan dengan jumlah 341 penderita, Babat 208 penderita, Paciran 176 penderita, Ngimbang 118 penderita dan Mantup 116 penderita. $^{4}$

TB merupakan penyakit yang dapat dicegah dengan vaksin $\mathrm{BCG}$ dan dapat diobati dengan obat anti tuberkulosis (OAT). Hanya saja pengobatan TB dengan OAT membutuhkan waktu yang lama yaitu minimal 6 bulan yang dibagi menjadi fase intensif dan lanjutan. Konsumsi OAT dalam waktu lama dapat menyebabkan ketidakpatuhan atau putus berobat (drop out). Ketidakpatuhan pasien TB terhadap pengobatan dapat meningkatkan risiko terjadinya multiple drug resistent $T B$ (MDRTB) yang sangat berbahaya. WHO mengestimasi terdapat sekitar 484.000 kasus baru resistensi Rifampicin, yang merupakan terapi lini pertama dari $\mathrm{TB}$, yang mana $78 \%$ kasus tersebut mengalami MDR. ${ }^{1}$

Berdasarkan data dari Dinas Kesehatan Kabupaten Lamongan pada tahun 2016 didapatkan 29 pasien yang putus berobat atau drop out, kemudian pada 2017 ada 14 pasien yang drop out, dan pada tahun 2018 meningkat menjadi 20 pasien. Rendahnya angka kesembuhan dan adanya pasien yang masih drop out salah satunya dapat disebabkan oleh ketidakpatuhan terhadap pengobatan karena berbagai faktor yang ada. Faktor yang mempengaruhi meliputi faktor predisposisi (Usia, jenis kelamin, tingkat pendidikan, dan pekerjaan), faktor pendorong (efek dari OAT), dan faktor penguat (dukungan keluarga, petugas kesehatan dan pelayanan kesehatan) ${ }^{5}$

Rendahnya tingkat pendidikan akan menyebabkan rendahnya tingkat pengetahuan termasuk dalam perilaku hidup bersih dan sehat (PHBS). Salah satu perilaku hidup bersih yang sering diabaikan oleh penderita TB yang memiliki tingkat pendidikan rendah adalah sering membuang dahak serta meludah sembarang tempat. ${ }^{6}$ Untuk menekan tingginya angka kejadian TB salah satunya adalah dengan melakukan pengobatan secara tuntas bagi penderita TB minimal selama 6 bulan. Pengobatan tuntas bisa dilakukan bila penderita patuh terhadap pengobatannya. ${ }^{3}$ Oleh karena itu, penelitian ini dilakukan untuk mengetahui apakah ada hubungan antara tingkat pendidikan dengan kepatuhan berobat penderita TB paru di Wilayah Kabupaten Lamongan.

\section{METODE}

Penelitian ini bersifat deskriptif analitik dengan desain yang digunakan yaitu cross sectional dimana penelitian ini bertujuan untuk mengetahui hubungan tingkat pendidikan dengan kepatuhan berobat penderita TB paru di Wilayah Kabupaten Lamongan. Penelitian ini dimulai dengan pengambilan data di Dinas Kesehatan 
Kabupaten lamongan. Data sekunder tersebut kurang lengkap, sehingga harus mencari data sekunder lanjutan di beberapa Puskesmas yang ada di Kabupaten Lamongan sesuai dengan data dari Dinas Kesehatan sebelumnya. Dari 33 Puskesmas di Kabupaten Lamongan, ada sekitar 18 Puskesmas yang harus didatangi untuk pengambilan data. Penelitian ini dilaksanakan pada Desember 2019. Sampel yang digunakan pada penelitian ini adalah pasien TB paru yang dinyatakan drop out (putus berobat) dan pasien TB paru yang dinyatakan sembuh oleh tenaga medis pada Januari 2016 - Desember 2018. Pengambilan sampel menggunakan simple random sampling dengan jumlah sampel sebesar 110 responden, 55 pasien TB paru drop out (putus berobat) dan 55 pasien TB paru yang dinyatakan sembuh. Kegagalan pengobatan TB (drop out) oleh WHO didefinisikan sebagai terhentinya pengobatan selama dua bulan berturut-turut atau lebih setelah menjalani minimal 1 bulan pengobatan.

Pengumpulan data pada penelitian menggunakan menggunakan data sekunder saja. Data sekunder menggunakan rekam medik penderita TB paru yang telah menyelesaikan pengobatan di Puskesmas Wilayah Kabupaten Lamongan pada Januari 2016 - Desember 2018. Ketidakpatuhan pasien terhadap pengobatan TB ditandai dengan pengobatan yang tidak selesai (drop out) berdasarkan data rekam medis. Analisis data yang digunakan pada penelitian ini adalah analisis univariat dan bivariat. Uji yang digunakan adalah uji analisis non parametrik dengan uji Koefisien Kontingensi. ${ }^{7}$ Studi ini telah disetujui oleh Komite Etik dari Fakultas Kedokteran Universitas Muhammadiyah Surabaya dengan no sertifikat laik etik 0764/SER/11.3.AU/A/2019.

\section{HASIL DAN PEMBAHASAN}

\section{Hasil}

Jumlah responden dalam penelitian ini sebanyak 110 responden yang terdiri dari 55 pasien TB paru drop out (putus berobat) dan 55 pasien TB paru yang dinyatakan sembuh. Data demografi dianalisis secara univariate dengan analisis deskriptif, yaitu untuk mengetahui jumlah serta persentase pada masing-masing kelompok. Hubungan antar variabel dianalisis menggunakan analisis bivariat menggunakan uji analisis non parametrik Koefisien Kontingensi.

\section{Data Demografi Penderita TB paru}

Berdasarkan Tabel 1.1, 110 responden menunjukkan bahwa karakteristik berdasarkan jenis kelamin terdiri dari laki-laki sebanyak $70(63,6 \%)$ dan perempuan sebanyak $40(36,4 \%)$. Sedangkan berdasarkan usia responden menunjukkan, usia 15-35 tahun sebanyak $24(21,8 \%)$, usia 35-55 tahun sebanyak 46 (41,8\%), usia 55-75 tahun sebanyak $39(35,5 \%)$, dan usia $>75$ tahun sebanyak $1(0,9 \%)$.

Tabel 1.1 Distribusi Frekuensi Data Demografi Responden Berdasarkan Usia dan Jenis Kelamin

\begin{tabular}{lcc}
\hline Jenis Kelamin & Jumlah & $\%$ \\
\hline Laki-laki & 70 & $63,6 \%$ \\
Perempuan & 40 & $36,4 \%$ \\
\hline Total & 110 & $100 \%$ \\
\hline Usia & Jumlah & $\%$ \\
\hline $15-35$ tahun & 24 & $21,8 \%$ \\
$35-55$ tahun & 46 & $41,8 \%$ \\
$55-75$ tahun & 39 & $35,5 \%$ \\
$>75$ tahun & 1 & $0,9 \%$ \\
\hline
\end{tabular}


Tabel 1.1 Distribusi Frekuensi Data Demografi Responden Berdasarkan Usia dan Jenis Kelamin

\begin{tabular}{lcc}
\hline Jenis Kelamin & Jumlah & $\%$ \\
\hline Total & 110 & $100 \%$ \\
\hline
\end{tabular}

Tabel 1.2 Distribusi Frekuensi Responden Berdasarkan Tingkat Pendidikan

\begin{tabular}{lcc}
\hline Tingkat Pendidikan & Jumlah & $\%$ \\
\hline Tidak tamat SD & 12 & $10,9 \%$ \\
SD & 35 & $31,8 \%$ \\
SMP & 27 & $24,5 \%$ \\
SMA & 29 & $26,4 \%$ \\
Perguruan Tinggi & 7 & $6,4 \%$ \\
\hline Total & 110 & $100 \%$ \\
\hline
\end{tabular}

Tabel 1.3 Distribusi Frekuensi Responden Berdasarkan Kepatuhan Berobat

\begin{tabular}{lcc}
\hline Kepatuhan Berobat & Jumlah & $\%$ \\
\hline Patuh & 55 & $50 \%$ \\
Tidak patuh & 55 & $50 \%$ \\
\hline Total & 110 & $100 \%$ \\
\hline
\end{tabular}

\section{Tingkat pendidikan Penderita TB Paru}

Berdasarkan Tabel 1.2 menunjukkan bahwa tingkat pendidikan responden yang tidak tamat SD sebanyak $12(10,9 \%)$, SD sebanyak 35 (31,8\%), SMP sebanyak 27 $(24,5 \%)$, SMA sebanyak $29(26,4 \%)$, dan perguruan tinggi sebanyak $7(6,4 \%)$.

\section{Kepatuhan Berobat Penderita TB Paru}

Berdasarkan Tabel 1.3 menunjukkan bahwa kepatuhan berobat responden yang patuh sebanyak $55(50 \%)$ dan yang tidak patuh sebanyak $55(50 \%)$.

\section{Hubungan Tingkat Pendidikan dengan Kepatuhan Berobat Penderita TB Paru}

Berdasarkan Tabel 1.4 menunjukkan bahwa responden dengan tingkat pendidikan tidak tamat SD yang patuh berobat sebanyak $4(33,3 \%)$ dan yang tidak patuh sebanyak 8 $(66,7 \%)$. Responden dengan tingkat pendidikan SD yang patuh berobat sebanyak $13(37,1 \%)$ dan yang tidak patuh sebanyak 22 $(62,9 \%)$. Untuk responden dengan tingkat pendidikan SMP yang patuh berobat sebanyak $12(44,4 \%)$ dan yang tidak patuh sebanyak 15 $(55,26 \%)$. Responden dengan tingkat pendidikan SMA yang patuh berobat sebanyak $21(72,4 \%)$ dan yang tidak patuh sebanyak 8 (27,6\%). Responden dengan tingkat pendidikan Perguruan Tinggi yang patuh berobat sebanyak $5(71,4 \%)$ dan yang tidak patuh sebanyak $2(28,6 \%)$. 
Tabel 1.4 Tabulasi silang Tingkat Pendidikan dengan Kepatuhan Berobat serta Hasil Analisis dengan Koefisien Kontingensi

\begin{tabular}{|c|c|c|c|c|c|c|}
\hline \multirow{2}{*}{ Tingkat Pendidikan } & \multicolumn{4}{|c|}{ Kepatuhan Berobat } & \multirow{2}{*}{ Total } & \multirow{2}{*}{$\%$} \\
\hline & Patuh & $\%$ & Tidak patuh & $\%$ & & \\
\hline \multicolumn{7}{|l|}{ Tingkat Pendidikan } \\
\hline Tidak tamat SD & 4 & $33,3 \%$ & 8 & $66,7 \%$ & 12 & $100 \%$ \\
\hline SD & 13 & $37,1 \%$ & 22 & $62,9 \%$ & 35 & $100 \%$ \\
\hline SMP & 12 & $44,4 \%$ & 15 & $55,6 \%$ & 27 & $100 \%$ \\
\hline SMA & 21 & $72,4 \%$ & 8 & $27,6 \%$ & 29 & $100 \%$ \\
\hline Perguruan Tinggi & 5 & $71,4 \%$ & 2 & $28,6 \%$ & 7 & $100 \%$ \\
\hline Total & 55 & $50 \%$ & 55 & $50 \%$ & 110 & $100 \%$ \\
\hline
\end{tabular}

Hasil Uji Chi Square $=$ p: 0,026 $(p<0,05)$

\section{Pembahasan}

Walaupun rejimen OAT untuk pengobatan TB terlah ditemukan dari tahun 1980, tetapi TB masih merupakan salah satu masalah kesehatan utama di dunia sampai saat ini. ${ }^{1}$ Masalah kesehatan yang terkait dengan TB lebih banyak dialami di negara-negara berkembang termasuk di Indonesia. Dari studi global ditemukan ada berbagai faktor yang dapat mempengaruhi penanganan penyakit TB diantaranya adalah tingkat sosioekonomi yang rendah, banyaknya tuna wisma yang tidak memiliki tempat tinggal, keterbatasan makanan, tingkat pengangguran yang tinggi, tingkat pendidikan yang rendah, dukungan sosial yang rendah, serta kurangnya komunikasi yang intensif antara tenaga kesehatan dan pasien. ${ }^{8-9}$

Kegagalan pengobatan TB oleh WHO didefinisikan sebagai terhentinya pengobatan selama dua bulan berturut-turut atau lebih setelah menjalani minimal 1 bulan pengobatan. ${ }^{10}$ Kegagalan pengobatan biasanya diawali oleh ketidakpatuhan pasien dalam berobat. Ada beberapa cara untuk mengetahui kepatuhan berobat yaitu: adanya keputusan dokter dari hasil pemeriksaan, hasil pengamatan jadwal selama pengobatan, penilaian berdasarkan tujuan pengobatan, perhitungan jumlah tablet diakhir pengobatan, pengukuran kadar obat dalam darah dan urin, serta wawancara pada pasien dan pengisian formulir khusus. Selain itu, kepatuhan berobat pasien dapat diketahui melalui 3 cara yaitu perhitungan sisa obat secara manual, perhitungan sisa obat berdasarkan suatu alat elektronik serta pengukuran berdasarkan biokimia (kadar obat) dalam darah/urin. ${ }^{11}$ Pada penelitian ini, kriteria pasien yang tidak patuh terhadap pengobatan adalah pasien yang tidak tuntas melakukan pengobatan TB selama 6 bulan (drop out) sesuai dengan kriteria WHO.

Ketidakpatuhan terhadap pengobatan merupakan salah satu faktor terpenting dan merupakan salah satu hambatan terbesar dalam penanganan TB di dunia, serta merupakan faktor yang paling berkontribusi terhadap kegagalan pengobatan. ${ }^{12}$ Menurut Rossenstock, kepatuhan dipengaruhi oleh persepsi individu tentang kerentanan terhadap sakit dan kegawatan suatu penyakit. ${ }^{13}$ Selain itu, berdasarkan teori preced-proced oleh Lawrence green menyebutkan bahwa terdapat 3 faktor yang dapat mempengaruhi kepatuhan berobat, diantaranya adalah faktor predisposisi (usia, jenis kelamin, tingkat pendidikan, dan pekerjaan), faktor pendorong (efek dari OAT), dan faktor penguat (dukungan keluarga, petugas kesehatan dan pelayanan kesehatan). ${ }^{14}$

Pendidikan merupakan suatu upaya yang direncanakan agar individu atau masyarakat dapat melakukan apa yang diajarkan oleh perilaku pendidikan. Seseorang yang berpendidikan tinggi, bila mengalami sakit akan semakin membutuhkan fasilitas pelayanan kesehatan sebagai tempat berobat bagi dirinya dan keluarganya. Semakin 
individu memiliki tingkat pendidikan tinggi, maka akan semakin menyadari bahwa kesehatan merupakan suatu hal penting bagi kehidupan sehingga termotivasi untuk melakukan kunjungan ke faslitas pelayanan kesehatan yang lebih baik. Selain itu, individu tersebut akan lebih mudah menerima informasi serta meningkatkan pengetahuan yang dimiliki dan begitupun sebaliknya. ${ }^{15}$

Pada penelitian ini, tingkat pendidikan SD lebih besar dibandingkan dengan yang lain. Hal ini karena, mayoritas penderita adalah masyarakat perdesaan yang rata-rata pekerjaannya adalah seorang petani, pedagang, serta nelayan yang hanya sebagai tamatan SD. Motivasi dalam belajar mereka sangat rendah karena tuntutan dari segi perekonomian dan lingkungan sekitar yang juga mempengaruhi. Begitupun yanghanya lulus sampai SMP maupun SMA, selain karena kurangnya motivasi belajar, biaya juga menjadi alasan untuk tidak melanjutkan ke jenjang pendidikan yang selanjutnya. Hal ini yang menjadi salah satu faktor kepatuhan dalam berobat, terutama mempengaruhi pengetahuan mereka dalam melakukan pengobatan. Semakin individu memiliki tingkat pendidikan tinggi, maka akan semakin menyadari bahwa kesehatan merupakan suatu hal penting bagi kehidupan sehingga termotivasi untuk melakukan kunjungan ke pusat-pusat pelayanan kesehatan yang lebih baik. $^{11}$

Berdasarkan hasil penelitian yang dilakukan didapatkan tabulasi silang antara tingkat pendidikan dengan kepatuhan berobat yaitu, responden yang patuh dengan tingkat pendidikan SMA yaitu sejumlah 21 responden lebih banyak dibandingkan dengan tingkat pendidikan tidak tamat SD sejumlah 4, SMP sejumlah 12 dan perguruan tinggi sejumlah 5. Sementara itu, untuk responden yang tidak patuh dengan tingkat pendidikan SD yaitu sejumlah 22 responden lebih banyak dibandingkan deengan tingkat pendidikan tidak tamat SD sejumlah 12 responden, SMP sejumlah 15, SMA sejumlah 8 orang dan perguruan tinggi sejumlah 2 orang. Penelitian ini membuktikan bahwa semakin rendahnya tingkat pendidikan semakin banyak yang tidak patuh terhadap pengobatan.

Dari hasil analisis uji statistik menggunakan Koefisien Kontingensi didapatkan nilai signifikansi 0,026 dengan nilai $\mathrm{p}<0,05$ yang berarti adanya hubungan tingkat pendidikan dengan kepatuhan berobat penderita TB Paru. Hasil penelitian ini juga sejalan dengan penelitian sebelumnya dimana hasil uji chi square didapatkan hasil p 0,021 $(<0,05)$ yang artinya terdapat hubungan bermakna antara pendidikan terakhir dengan kepatuhan berobat penderita TB. ${ }^{11}$ Hasil penelitian ini dikaitkan dengan pengetahuan pasien yang minim akan pengobatan dimana pengetahuan tersebut dipengaruhi salah satunya adalah oleh tingkat pendidikan dari penderita TB paru tersebut yang mayoritas tingkat pendidikannya adalah tamatan SD. Namun, pengetahuan juga tidak harus sebanding dengan tingkat pendidikan karena pengetahuan bisa saja didapatkan dari bertanya ataupun membaca.

Menurut suatu studi mengatakan bahwa tingkat pendidikan pasien TB akan mempengaruhi tingkat pengetahuan dan daya serapnya dalam hal pencegahan penularan serta pengobatan TB. ${ }^{15}$ Penderita yang memiliki tingkat pengetahuan yang kurang akan cenderung untuk tidak melakukan pengobatan karena baginya melakukan pengobatan dan tidak berobat akan sama saja hasilnya. Pengetahuan juga bisa dipengaruhi oleh persepsi misalnya persepsi sebagian penderita yang melihat kejadian yang dialami oleh keluarganya sendiri. Keluarga yang sama-sama terdiagnosa TB dan melakukan pengobatan pun akan tetap meninggal. Selain itu, dalam suatu studi yang lain menyebutkan bahwa semakin rendahnya pengetahuan dan pendidikan maka makin rendah pula kesadaran pasien tersebut terhadap bahayanya penyakit tersebut pada dirinya dan lingkungannya, serta semakin rendah pula kesadarannya dalam melakukan pengobatan secara tuntas. ${ }^{16}$

Penelitian ini masih memiliki keterbatasan diantaranya, ketidakpatuhan pada pasien baru diukur bila pasien sudah 
mengalami putus berobat (drop out) selama 2 bulan berturut-turut, setelah mendapatkan pengobatan minimal 1 bulan. Untuk penelitian selanjutnya dapat disarankan untuk meneliti ketidakpatuhan pada saat awal pengobatan tanpa harus menunggu 2 bulan putus obat serta dilakukan wawancara secara langsung untuk menggali faktor-faktor yang berpengaruh terhadap ketidakpatuhan tersebut.

\section{KESIMPULAN}

Dalam studi ini ditemukan mayoritas tingkat pendidikan penderita TB di Kabupaten Lamongan pada kurun waktu 2016-2018 adalah tamatan SD. Terdapat hubungan antara tingkat pendidikan dengan kepatuhan berobat serta angka drop out pada penderita TB paru.

\section{DAFTAR PUSTAKA}

1. WHO. Tuberculosis. Key facts. 2020. Available from: URL: HIPERLINK https://www.who.int/en/news-room/factsheets/detail/tuberculosis

2. Majdawati A. Uji diagnosis lesi foto thorax pada penderita dengan klinis tuberculosis paru mutiara medika. 2010;10(2).180-188

3. Dinas Kesehatan Kabupaten Lamongan. Profil kabupaten lamongan 2016. (ebook). 2017.

4. Badan Pusat Statistik Lamongan (BPS). Kabupaten lamongan dalam angka lamongan regency in figures. Report. Badan Pusat Statistik Lamongan. Nomor Katalog : 1102001.3524; Nomor Publikasi : 35240.1803; ISSN / ISBN : 0215-5621. 2018.

5. Wulandari AA. Nurjazuli M. Sakundarno A. Faktor risiko dan potensi penularan tuberkulosis paru di kabupaten kendal, jawa tengah. Jurnal Kesehatan Lingkungan Indonesia. 2015;14(1):7-13

6. Nurjana MA. Faktor risiko terjadinya tuberculosis paru usia produktif (15-49 tahun) di indonesia. Media Litbangkes. 2015;25(3):165-167.

7. Maulidia DF. Hubungan antara dukungan keluarga dan kepatuhan minum obat pada penderita tuberkulosis di wilayah ciputat tahun 2014. [Skripsi]. Universitas Islam Negeri Syarif Hidayatullah. 2014. Tersedia di: http://repository.uinjkt.ac.id .

8. Hargreaves JR, Boccia D, Evans CA, Adato M, Petticrew M, Porter JDH. The social determinants of tuberculosis: from evidence to action, framing health matters. Am J Public Health. 2011;101(4): 654-62.

9. Suk JE, Manissero D, Büscher G, Semenza JC. Wealth inequality and tuberculosis elimination in europe. Emerg Infect Dis. 2009;15(11):1812-4.

10. Floyd K, Broekmans JF. Intervention to reduce tuberculosis mortality and transmission in low- and middle-income countries. Bulletin on the World Health Organization. 2002;80:217-227.

11. Prayogo AHE. Faktor-faktor yang mempengaruhi kepatuhan minum obat anti tuberculosis pada pasien tuberculosis paru di puskesmas pamulang kota tnagerang selatan propinsi banten periode januari-2013. [Skripsi]. Universitas Islam Negeri Syarif Hidayatullah. 2013. Tersedia

di:http://repository.uinjkt.ac.id/dspace/bits tream/123456789/26334/1/Akhmad\%20H udan\%20Eka\%20Prayogo-fkik.pdf

12. Castelnuovo B. A review of compliance to anti tuberculosis treatment and risk factors for defaulting treatment in sub saharan africa. Afr Health Sci. 2010;10:320-324.

13. Budi IS, Ardillah Y, Sari IP, Setiawati D. Analisis faktor risiko kejadian penyakit tuberculosis bagi masyarakat daerah kumuh kota palembang. Jurnal Kesehatan Lingkungan Indonesia. 2018;7(2):88-94

14. Wulandari AA, Nurjazuli M, Sakundarno A. Faktor risiko dan potensi penularan tuberkulosis paru di kabupaten kendal, jawa tengah. Jurnal Kesehatan Lingkungan Indonesia, 2015.14(1):7-13.

15. Setyowati DRD, Mutmainah N. Evaluasi tingkat kepatuhan penggunaan obat 
tuberkulosis di puskesmas kabupaten Sukoharjo. Naskah Publikasi. 2012. Universitas Muhammadiyah Surakarta. Tersedia di: http://eprints.ums.ac.id

16. Widyastuti H. Faktor-faktor yang berhubungan dengan kepatuhan berobat pasien tb paru di balai kesehatan paru masyarakat kota pekalongan. [Skripsi]. Universitas Negeri Semarang. 2016. 